\title{
Jan Chłosta
}

\section{JUBILEUSZ ROBERTA PIECZKOWSKIEGO}

5 października 2020 r. rodowity Warmiak Robert Pieczkowski ukończył 90 lat i upłynęło 30 lat, odkąd przebywa na emeryturze, zawsze jednak uczestniczy we wszystkich spotkaniach poświęconych Warmii, w tym także organizowanych przez Zespół Szkół Ekonomiczno-Handlowych im. Polaków spod znaku Rodła w Olsztynie.

Wywodzi się z rodziny polskich Warmiaków Łucji i Augusta Pieczkowskich ze Spręcowa. Wieś ta w przeszłości znajdowała się na pograniczu polsko-niemieckim. Rodzice Roberta mieli tam znaczne gospodarstwo rolne. Stryjem jego Matki Łucji był ksiądz Walenty Barczewski, od 1894 r. do swej śmierci w 1928 roku, proboszcz parafii w Brąswałdzie, literat, etnograf i historyk Warmii, który opisał jej południową część czyli polską Warmię, w takich książkach jak Kiermasy na Warmii, Geografia polskiej Warmii.

Pani Łucja była od 1925 r. członkiem Związku Polaków w Niemczech. Uczestniczyła w pracach Chóru im. Feliksa Nowowiejskiego w Olsztynie, dwa razy w tygodniu z rodzinnych Jarot, dzisiaj dzielnicy Olsztyna, dochodziła na próby do Olsztyna, a potem występami chóru, uświetniała różne uroczystości narodowe i kościelne. Siłą rzeczy po zawarciu związku małżeńskiego i osiedleniu się w Spręcowie, te kontakty nieco się rozluźniły. $\mathrm{Na}$ świat kolejno przychodziły dzieci, a i w polu niekiedy trzeba było pomagać. W rodzinie Łucji i Augusta Pieczkowskich przyszło na świat sześciu chłopców i córka Irena.

Gdyby życie Roberta Pieczkowskiego wiązać z tym wszystkim, co łączyło go z tą ziemią od 1930 r., to trzeba napisać, że uczęszczał do szkoły niemieckiej w rodzinnym Spręcowie, bo tam polskiej nie było, a języka polskiego nauczył się w domu. Przeżył dramatyczne wkroczenie Rosjan do Prus Wschodnich w styczniu 1945 r. Wtedy to funkcjonariusze NKWD aresztowali o rok starszego brata Huberta i deportowali go do pracy w głąb Rosji sowieckiej, skąd nigdy nie powrócił. W momencie aresztowania Rosjanie nie pytali czy Polak czy Niemiec? Wykonywali rozkazy.

W odróżnieniu od większości młodych ludzi urodzonych na Warmii, Robert zabrał się do nauki. Nie wszyscy tak postępowali, większość raczej ociągała się z kształceniem. Stąd tak mało jest i było wykształconych rodzimych Warmiaków. Zabiegali jednak o to rodzice Roberta. Napisał o tym w tekście drukowanym w 1953 r. w „Słowie na Warmii i Mazurach”: „Najbardziej przywiązanie rodziców do polskości wyraziło się w wychowaniu 
swoich dzieci na co dzień, w odpowiednim przygotowaniu do podjęcia nauki w polskiej szkole". Jak prawie każdy matematyk pisał oszczędnie, zawsze więcej o innych niż o sobie.

A z nauką na początku nie było łatwo. Musiał przecież znacznie lepiej opanować polski język literacki. Na szczęście spotykał wyrozumiałych i dobrze przygotowanych nauczycieli, którzy byli jego przewodnikami w bliższym poznawaniu kultury polskiej. Wśród nich ważną role odegrała pani Profesor Jadwiga Lindner. W $1950 \mathrm{r}$. ukończył Liceum Pedagogiczne i zgodnie z obowiązującymi wówczas przepisami, musiał odbyć co najmniej roczny nakaz pracy nauczycielskiej. Zatem tamten 1951 rok, powtórzę to jeszcze raz, mógłby posłużyć do świętowania 60-lecia podjęcia przez pana Pieczkowskiego pracy nauczycielskiej. Jednak Robert Pieczkowski wciąż myślał o studiach. Podjął je w tym samym 1951 r. na Wydziale Matematycznym Uniwersytetu Mikołaja Kopernika w Toruniu. Tą samą drogą poszedł młodszy o 2 lata brat Augustyn, a Henryk ukończył Wyższą Szkołę Rolniczą w Olsztynie. Po ukończeniu uniwersytetu w 1955 r. Robert został nauczycielem matematyki w olsztyńskich technikach, najpierw zwanym Rachunkowości potem Ekonomicznym. W latach 1971-1990 byl wicedyrektorem Instytutu Kształcenia Nauczycieli i Badań Oświatowych w Olsztynie, która to placówka potem przejmowała inne nazwy. W $1990 \mathrm{r}$. przeszedł na zasłużoną emeryturę, po 40 latach pracy nauczycielskiej.

Robert Pieczkowski raczej stronił przed angażowaniem się w pracę polityczną. Był zawsze bezpartyjnym, lecz, tak jak wielu Polaków, po pamiętnej odwilży, w „polskim Październiku” 1956 r., dał się wciągnąć w działania publiczne. Zaangażował się w działalność krótko istniejącego Warmińsko-Mazurskiego Towarzystwa Społeczno-Kulturalnego w Olsztynie, w 1958 r. został nawet wiceprezesem Zarządu Głównego tego stowarzyszenia.

W sposób szczególny zawsze Robert Pieczkowski odnosił się do dokonań swego wielkiego antenata księdza Walentego Barczewskiego. Jego blaskiem oświetlał innych krewnych: siostrę księdza Barbarę Barczewską mieszkającą w Spręcowie, zmarłą w 1954 r., która zawsze okazywała wzruszenie kiedy Robert brał skrzypce do ręki i intonował kościelną pieśń Po górach dolinach. Wspominał o działalności narodowej innych Barczewskich. Jeden z nich August zapisał się jako aktywny działacz plebiscytowy w 1920 r. tu na Warmii w okresie poprzedzającym plebiscyt, potem musiał uchodzić na ziemię lubawską, a Alfons Barczewski był również nauczycielem szkół polskich w latach międzywojnia na południowej Warmii, później został adwokatem. Mniej Robert mówił o sobie, o żonie, dwóch córkach, wnukach. Miałem nawet do Roberta ciche pretensje, że w swoich wspomnieniach zawartych w książce Warmińskie pokolenia napisał tyle o księdzu Barczewskim, a tak mało o sobie. 